UDC 378.147:377]:63](477)(043.3)

\title{
Implementation of E-Learning Innovative Technologies in The Process of Studying Foreign Languages by Students of Agrarian Universities
}

\author{
Bilotserkovets M.", Gubina O., Kobzhev 0. \\ Sumy National Agrarian University, Sumy, Ukraine
}

Received: 28.02.2020 Accepted: 26.03 .2020

\begin{abstract}
The article reveals the implementation of innovative e-learning technologies in the process of mastering the discipline "Foreign language in the professional direction" by students of agricultural universities. Actual approaches to teaching humanities require the use of information-communication technologies (ICT) for educational purposes, that allows increasing the volume of educational materials and modernizing it with the help of multimedia presentation tools. The application of information-communication technologies contributes to the students' mastering of foreign languages knowledge as a tool of communication in a global society and the development of their information competencies. Particular attention is paid to the characteristics of the content, structure and objectives of the electronic training course on learning English, German, Ukrainian and Russian as foreign languages for students of the distance learning form of Sumy National Agrarian University. The presented distance learning course is an innovative development exemplar, that provides learners' study of educational textual, audio and video materials in the mode of independent work with a computer and facilitates regulating the order of interaction of students with a computer. Such interaction contributes to the improvement of the efficiency of the educational process through the introduction of new methods and means of teaching educational materials; stimulates students' interest in the study of foreign languages through the use of innovative information-communication technologies; responsiveness of the feedback and the possibility of direct consultation with the teacher in the educational environment of the Moodle platform. The analysis of the experimental study results showed predominantly sufficient and high levels of humanitarian knowledge in experimental groups that were trained on the basis of the electronic course in the educational environment of Moodle platform; in contrast to the low and initial levels in the control groups.
\end{abstract}

Key words: distance learning, experimental research, foreign language, information-communication technologies, Moodle educational platform, students of agricultural professions.

\section{Впровадження інноваційних технологій електронного навчання у процес засвоєння іноземних мов студентами аграрних 3ВО}

\author{
Білоцерковець М. А., Губіна О. Ю., Кобжев О. М. \\ Сумський національний аграрний університет, Суми, Україна
}

\begin{abstract}
Анотація. У статті розкрито впровадження інноваційних технологій електронного навчання у процес засвоєння студентами аграрних спеціальностей гуманітарних знань, зокрема 3 навчальної дисципліни «Іноземна мова за професійним спрямуванням». Актуальні підходи до викладання гуманітарних знань потребують застосування інформаційно-комунікаційних технологій (IКТ) освітнього призначення, які дозволяють збільшити обсяг освітнього матеріалу та модернізувати його мультимедійними засобами презентації. Залучення інформаційно-комунікативних технологій сприяє оволодінню студентами іноземними мовами як інструментом комунікації у глобалізованому суспільстві та розвиткові їхніх інформаційних профресійних компетентностей. Особливу увагу приділено характеристиці змісту, структури та завдань електронного навчального курсу з вивчення іноземних (англійської і німецької) мов та української і російської мов як іноземних для студентів дистанційної форми навчання Сумського національного аграрного університету. Представлений навчальний дистанційний курс $є$ інноваційною розробкою, що забезпечує вивчення освітнього текстового, аудіо та відео матеріалу в режимі самостійної роботи з комп'ютером і дозволяє регламентувати порядок взаємодії студентів із комп'ютером. Така взаємодія сприяє підвищенню продуктивності й ефективності освітнього процесу через впровадження новітніх методів і засобів викладання освітного матеріалу; стимулюванню інтересу студентів до вивчення іноземних мов завдяки застосуванню
\end{abstract}

Corresponding Author: Bilotserkovets Marina. Tel. +38(066)007-69-04. E-mail: mbilotserkovets@yahoo.com. Sumy National Agrarian University, G.Kondratiyev street, 160, Sumy, Ukraine, 40000.

Відповідальний автор: Білоцерковець Марина Анатоліівна. +38(066)007-69-04. E-mail: mbilotserkovets@yahoo.com. Сумський національний аграрний університет, вул. Г. Кондратьєва, 160, Суми, Україна, 40000. 
інноваційних інформаційно-комунікативних технологій; діагностиці якості засвоєних знань, оперативності зворотного зв'язку і можливості безпосередніх консультацій із викладачем в освітньому середовищі платформи Moodle. Аналіз результатів експериментального дослідження засвідчив переважно достатній і високий рівні гуманітарних знань в експериментальних групах, навчання яких відбувалося на основі електронного курсу в освітньому середовищі платфрорми Moodle; на відміну від низького і початкового рівнів у контрольних групах.

Ключові слова: дистанційне навчання, іноземна мова, інформаційно-комунікаційні технології, студенти аграрних спеціальностей, освітня платформа Moodle, експериментальне дослідження.

\title{
Внедрение инновационных технологий электронного обучения в процесс освоения иностранных языков студентами аграрных вузов
}

\author{
Белоцерковец М. А., Губина О. Ю., Кобжев А. Н. \\ Сумский национальный аграрный университет, Сумы, Украина
}

\begin{abstract}
Аннотация. В статье раскрыто внедрение инновационных технологий электронного обучения в процесс освоения студентами аграрных специальностей гуманитарных знаний, в частности, знаний по учебному предмету «Иностранный язык профессионального направления». Актуальные подходы к преподаванию гуманитарных знаний требуют применения инфрормационно-коммуникационных технологий (ИКТ) образовательного назначения, которые позволяют увеличить объем учебного материала и модернизировать его мультимедийными средствами презентации. Привлечение информационно-коммуникативных технологий способствует овладению студентами иностранными языками как инструментом коммуникации в глобальном обществе и развитию их профессиональных информационных компетентностей. Особое внимание уделено характеристике содержания, структуры и задач электронного учебного курса по изучению английского и немецкого языков, а так же украинского и русского языков как иностранных для студентов дистанционной формы обучения Сумского национального аграрного университета. Представленный учебный дистанционный курс является инновационной разработкой, обеспечивающей изучение образовательного материала в режиме самостоятельной работы с компьютером и позволяет регламентировать порядок взаимодействия студентов с компьютером. Такое взаимодействие способствует повышению эффективности образовательного процесса через внедрение новейших методов и средств преподавания учебных материалов; стимулирует интерес к изучению иностранных языков благодаря применению инновационных информационно-коммуникативных технологий; обеспечивает оперативность обратной связи и возможность непосредственных консультаций с преподавателем в образовательной среде Moodle. Анализ результатов экспериментального исследования показал преимущественно достаточный и высокий уровни гуманитарных знаний в экспериментальных группах, обучение которых происходило на основе электронного курса в образовательной среде платформы Moodle; в отличие от низкого и начального уровней в контрольных группах.

Ключевые слова: дистанционное обучение, иностранный язык, информационно-коммуникационные технологии, студенты аграрных специальностей, образовательная платформа Moodle, экспериментальное исследование.
\end{abstract}

\section{Bcmyn}

В умовах інформаційного суспільства майбутній фахівець аграрного профрілю має володіти наступними якостями: здатністю і готовністю до виваженого ризику, до безперервного навчання, постійного самовдосконалення і прагнення нового, відзначатися критичним та креативним мисленням, достатнім володінням іноземними мовами як інструментом комунікації в глобальному світі, розвиненими інформаційними компетентностями. Усе це зумовило створення сучасної парадигми аграрної освіти, яка, зокрема, передбачає впровадження інноваційних навчальних форм у вітчизняну систему вищої освіти, таких як організація навчально-виховного процесу за дистанційною формою навчання, відповідно до Наказу Міністерства освіти і науки України «Положення про дистанційне навчання» (2013) [6].

Mema cmammi - дослідити процес активізації гуманітарних знань, зокрема із дисципліни «Іноземна мова за профресійним спрямуванням» студентів аграрних спеціальностей засобами електронного навчального курсу, створеного на освітній платфрормі Moodle.

Гуманітарна змістова складова вищої аграрної освіти полягає в тому, щоб задовольняти пізнавальні інтереси та потреби студентів з питань сучасної політики, права, етики, рідної та іноземних мов, культурології, психології, педагогіки тощо, готувати студента не як «вузького» фахівця, який 
виконує чітко визначені стандартні функції, а багатогранну, гармонійну особистість, яка здатна розкрити і реалізувати власний потенціал. У Меморандумі ЮНЕСКО від 1994 р. наголошується, що тільки освіта, яка дає універсальні за своєю сутністю знання, є чинником стійкого розвитку країн і найкраще готує людину до життя, оскільки передбачає поглиблення загальнотеоретичної і загальнонаукової підготовки [5]. Вивчення гуманітарних дисциплін, як зазначає Д. Щепова, слугує для випускників аграрних спеціальностей основою формування системи наукової інформації та готовності до творчої і свідомої професійної діяльності [13]. Вважаємо, що сфрормовані гуманітарні знання допомагають студентамаграріям адаптуватися до сучасних суспільно-економічних відносин і розвитку міжнародних контактів, забезпечують мотивацію діяльності, поведінки, орієнтацію в суспільстві, формують прагнення досягти певних цілей відповідно до суспільних норм і навіть сприяють саморегуляції емоційних стресових переживань особистості [1].

Сучасність вимагає нових підходів до освітніх технологій освоєння гуманітарних знань. Інформаційно-комунікаційні технології (IКТ) освітнього призначення дозволяють збільшити обсяг матеріалу, що пропонується студентам для засвоєння, а також зробити цей матеріал більш цікавим, що значно впливає на результативність вивчення гуманітарних дисциплін. Студенти формують свої гуманітарні знання через процес активного залучення до навчання, отримуючи нові знання за допомогою необхідних ресурсів, спрямованих на асиміляцію нових і вже засвоєних гуманітарних знань. Залучення електронних ресурсів сприяє створенню середовища, де студенти можуть вільно ставити питання [16]. Активізація знань проводиться за допомогою конструювання ситуацій, максимально наближених до життя. Саме тому вже протягом певного періоду українські ЗВО для втілення у життя концепції дистанційної освіти досить активно розробляють курси в освітньому середовищі Moodle.

Проблемою використання інформаційно-комунікаційних технологій у системі вітчизняної вищої освіти займаються ряд науковців. Так, дослідник В. Биков [2] наводить найбільш всеохоплюючу в українській науці класифікацію технологій он-лайн навчання та доводить його актуальність та важливість для реалізації завдань сучасної системи вищої освіти. О. Губіна виокремлює такі суттєві переваги використання освітнього середовища Moodle, як доступність (можливість доступу до освіти різних соціальних груп); гнучкість (здатність слухачів навчатися у зручний час та у зручному місті); модульність (можливість сформувати індивідуальну навчальну програму, яка складається з набору незалежних курсів-модулів); паралельність (здійснення навчання одночасно з професійною діяльністю, без відриву від виробництва або іншого виду діяльності); економічність (економія витрат матеріальних, фінансових і людських ресурсів засобами використання технологій відкритої освіти) [3].

Ha перевагах індивідуального навчання завдяки платформі Moodle наголошує А. Томіліна. Науковець вважає, що робота з платформою підвищує контрольно-оцінювальні дії студента і викладача [10]. Дослідники Ю. Тріус та І. Герасименко підкреслюють суттєві переваги платформи Moodle, a саме: можливість розширення сфрери освітніх послуг і використання особистісно-орієнтованого підходу у навчанні студентів на всіх його етапах; реалізація завдань освітнього процесу за допомогою якісних навчальних матеріалів в електронному вигляді та засобів автоматизованого контролю [11].

I. Форостюк підкреслює важливість використання платформи Moodle у викладанні іноземних мов у вищіх навчальних закладах. Він зазначає, що дана комунікативна платформа у багатоканальному середовищі забезпечує організацію повноцінного навчального процесу, включаючи засоби навчання, систему контролю й оцінювання навчальної діяльності студентів [12]. Забезпечуючи індивідуалізацію навчального процесу, сучасні технології та вільний доступ до великої кількості е-ресурсів надають можливість викладачу, якій працює з платформою, створювати власну програму відповідного курсу, вдосконалюючи необхідні, на думку викладача, вміння та навички студентів [9]. А. Драч розглядає можливості інформаційно-комунікаційних технологій для формування гуманітарних знань, різноманітних іншомовної компетентностей із урахуванням психолінгвістичних закономірностей [4].

\section{II Матеріал і методи дослідження}

Прикладом успішного впровадження інноваційних технологій електронного навчання на освітній платформі Moodle в систему освіти майбутніх фахівців-аграріїв може слугувати академічна діяльність Сумського національного аграрного університету, на базі якого було створено центр дистанційного навчання. Системою керування дистанційного навчання $€$ платформа Moodle [7]. Навчання за 
дистанційними курсами відбувається через сайт центру дистанційного освіти. Термін навчання визначається в залежності від складності дистанційного курсу. Щоб розпочати навчання за дистанційною формою, потрібно зареєструватися на сайті Центру дистанційного навчання Сумського національного аграрного університету (заповнити заявку на дистанційне навчання), або надіслати заявку електронною поштою. Дистанційне навчання закінчується складанням контрольних тестів за курсом та отриманням Сертифікату. База курсів Центру дистанційного навчання Сумського національного аграрного університету формується з навчальних дисциплін за різними напрямами знань, зокрема гуманітарних.

Згідно навчальних планів, студенти Сумського національного аграрного університету засвоюють цикл гуманітарних дисциплін, а саме ділову українську мову, українську та російську мови як іноземні для студентів з інших країн, іноземні мови (англійську та німецьку), основи педагогіки, основи психології тощо. Для забезпечення вивчення даних дисциплін було створено та реалізовано електронні курси в освітньому середовищі Moodle. Перехід із традиційної заочної на дистанційну форму навчання відбувався поступово, отже постало питання дослідити, наскільки ефективним і доцільним $є$ вивчення гуманітарних дисциплін із застосуванням IКТ. Деякі з означених дисциплін $€$ новими для студентів аграрних спеціальностей, інші, такі, як українська й іноземна мови, вивчалися ними раніше, таким чином студенти мають активізувати вже засвоєні гуманітарні знання, щоб на їх основі фрормувати нові.

Розглянемо, як відбувається активізація гуманітарних знань студентів-аграріїв на прикладі експериментального впровадження ресурсу для вивчення навчальної дисципліни «Іноземна мова за професійним спрямуванням», яке проводилося на базі Сумського національного аграрного університету. Складовими експериментального дослідження з ефективності формування теоретичних знань на базі платформи Moodle було означено: учасників навчального процесу (науково-педагогічні працівники, студенти), нормативну базу (навчально-методичні плани; робочі програми), матеріальнотехнічне забезпечення (апаратне; телекомунікаційне; програмне забезпечення), відкриті освітні ресурси (електронні бібліотеки та база даних Сумського національного аграрного університету), види навчальної роботи (навчальні заняття; проектні завдання; практична підготовка; контрольні заходи).

Педагогічне дослідження відбувалося у двох експериментальних та двох контрольних групах із загальною кількістю 63 студентів 1-2 курсів дистанційної та заочної форм навчання протягом 2018-2019 навчального року. Викладання гуманітарних дисциплін в експериментальних групах відбувалося на базі платформи Moodle, студенти контрольних груп вивчали гуманітарні дисципліни за допомогою традиційних, лекційних та індивідуальних форм навчання. На початковому етапі було проведено попередній зріз знань, який дозволив визначити вихідні дані стосовно рівня гуманітарних знань студентів експериментальних і контрольних груп і зробити висновок, що вони є приблизно рівними.

Створення викладачами дидактичного забезпечення гуманітарних дисциплін як комп'ютерноорієнтованих засобів навчання на базі платформи Moodle, передбачало наступні етапи:

- аналіз змісту й мети академічної дисципліни, логіки викладення навчального матеріалу;

- детальний аналіз можливих лексико-граматичних помилок відповідно до кожного окремого блоку курсу академічної дисципліни;

- визначення обсягу й особливостей гуманітарних знань, які мають засвоїти майбутні фахівці аграрної галузі (концепції, поняття, положення, уявлення, факти, закони, гіпотези тощо);

- відбір і аналіз аудіовізуальних, мультимедійних та інших дидактичних засобів; визначення їх відповідності змісту і меті курсу академічної дисципліни, методичного призначення окремих складових і комплексу в цілому;

- визначення попереднього пізнавального досвіду студентів, на основі якого здійснюватиметься вивчення кожного питання теми;

- визначення методів і прийомів забезпечення активної пізнавальної діяльності студентів-аграріїв, міцного засвоєння гуманітарних знань, формування іншомовних компетентностей, удосконалення вмінь і навичок.

\section{III Результати}

Встановлено, що структура електронного навчального курсу Сумського національного аграрного університету з дисципліни «Іноземна мова за професійним спрямуванням» складається із цілісних 
частин, тобто модулів. Таке чітке структурування матеріалу $є$ необхідним, адже розбивка навчального матеріалу на блоки-модулі не тільки полегшує студенту вивчення цього матеріалу в режимі самостійної роботи з комп'ютером, а й дозволяє регламентувати порядок взаємодії студента з комп'ютером. Крім того, реалізація гіпертекстових переходів під час розробки електронного курсу повинна передбачати відособленість змістовних фрагментів тем.

Навчальний матеріал розподілено на два змістові модулі, кожен з яких містить теоретичний матеріал (електронний посібник, мультимедійні презентації лекцій, аудіо- та відео- навчальні матеріали, відеопрезентації лекцій); практичні роботи, для яких була створена підсистема вправ, спрямованих на формування й активізацію іншомовних лексико-граматичних знань, навичок і вмінь, разом 3 методичними рекомендаціями до їх виконання. Наступний блок містить завдання для самостійної роботи, а саме: індивідуальні завдання, критерії їх оцінювання як визначені форми взаємодії викладача зі студентами, вибрані форми зворотного зв'язку. Крім того, такий підхід забезпечує адаптивність навчальних матеріалів (можливість вибору рівня складності, обсягу, формату подання інформації: текстового, аудіо, відео і варіантів їх комбінування, послідовність виконання завдань, час на їх виконання). Завершується засвоєння навчального матеріалу модульним контролем, який містить пакет тестових завдань для визначення рівня засвоєння знань з тем, що відрізняються за рівнем складності за принципом від простішого до складнішого та за обсягом. На останньому етапі студенти проходять підсумкову атестацію, яку складають різнорівневі завдання, маючи можливість об'єктивно оцінити початковий і кінцевий рівень гуманітарних знань. Крім того, електронний курс містить блок «Консультації», який забезпечує безпосередній зв'язок з викладачем і можливість роботи в діалоговому режимі.

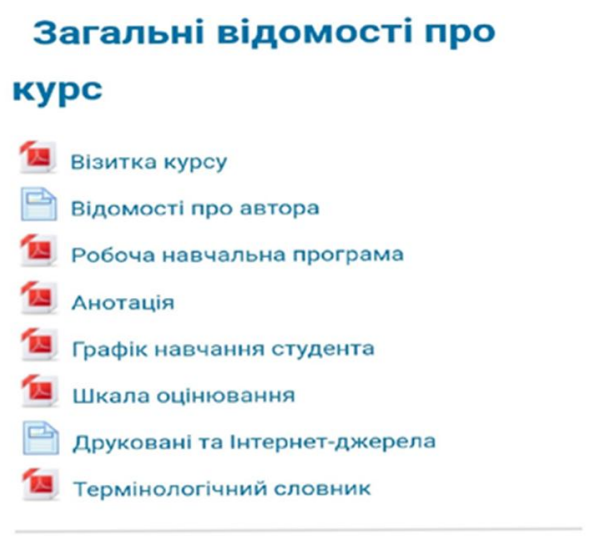

Модуль 1

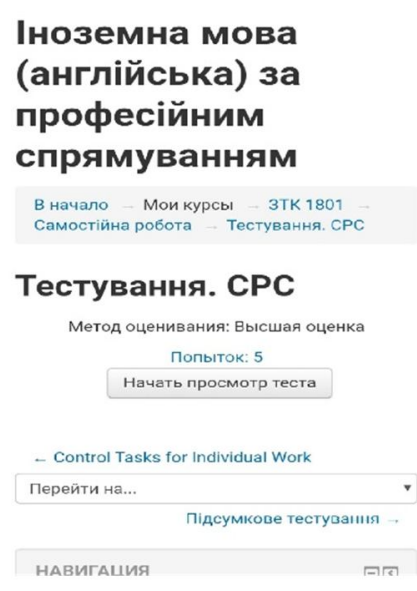

Рис 1. Приклад інтерфейсу електронного навчального курсу

Необхідно зауважити, що формувався і реалізовувався електронний ресурс для вивчення даної дисципліни викладачами кафедри іноземних мов, які пройшли спеціальні курси і тренінги для удосконалення власних інформаційно-комп'ютерних компетентностей.

Вивчення дисципліни на основі електронного ресурсу (в експериментальних групах) відбувалося протягом двох семестрів, після чого було проведено зріз знань студентів для порівняльного аналізу із рівнем знань студентів контрольних груп, які не використовували даного ресурсу. Кількісну обробку результатів вправ, усних і письмових відповідей здійснювали за коефріцієнтом знань (Кз) (враховували дослідження С. Поплавської [8]), який розраховували за формулою:

$$
\kappa_{3}=(\mathrm{a}+\mathrm{b}+\mathrm{c}) / 3,
$$

де a - системність, $b$ - повнота, c - оперативність.

Для переведення отриманих даних у числову форму використовували метод шкалювання: 5 балів означало високий рівень сформованості певної з визначених якостей гуманітарних знань, 3 - достатній рівень, 1 - низький, 0 - початковий рівень. 
Ураховували такі умови: якщо $3,67<К 3 \leq 5$, то рівень сформованості знань високий; якщо $2,33<К_{3} \leq 3,67$, сформованість знань відповідає достатньому рівню; $1<К_{3} \leq 2,33$ - знання на низькому рівні; $1<$ або = Кз - знання на початковому рівні. Для діагностування використовувалися тести, усні відповіді, результати комплексних контрольних робіт.

Для порівняння результатів, отриманих в експериментальній і контрольній групах, застосовували формулу, наведену у дослідженнях С. Поплавської [8]:

$$
\mathrm{t}=\frac{(P 1-P 2)}{\sqrt{\frac{\mathrm{P} 1 \mathrm{q} 1}{N 1}+\frac{\mathrm{P} 2 \mathrm{q} 2}{N 2}}},
$$

де P1, P2 - відсоткові показники змін у рівнях знань; q1, q2 - відповідно 100-P1, 100-P2; N1, N2 кількість досліджуваних об'єктів. Якщо $t>2$, то існує істотна відмінність, якщо $t<2$, то істотної відмінності немає. Якщо $t>3$, то відмінність безумовно достовірна.

Перевірка знань студентів експериментальних груп виявила значну позитивну динаміку, а саме: перед проведенням дослідження з активізації вивчення іноземних мов засобами електронного курсу в освітньому середовищі Moodle високий рівень знань мали 7\% студентів, достатній рівень був у 25\% студентів-учасників дослідження, 38\% і 30\% студентів експериментальних груп мали низький і початковий рівні гуманітарних знань відповідно. Аналіз даних після проведення дослідження засвідчив, що переважна кількість студентів експериментальних груп мала достатній $(45 \%)$ і високий $(21 \%)$ рівні гуманітарних знань, 34\% студентів мали низький рівень гуманітарних знань, початкового рівня гуманітарних знань встановлено не було. Дані аналізу результатів дослідження представлено на рис. 2.

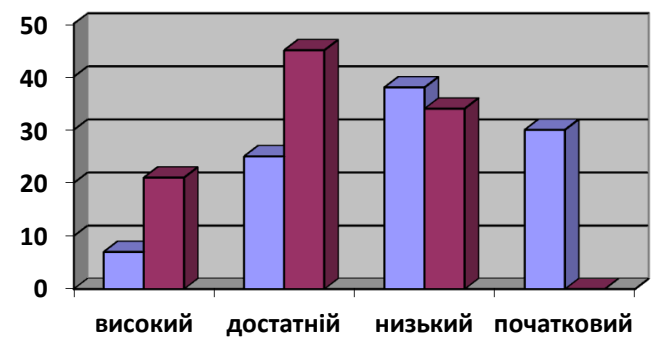

口до 口після

Рис. 2. Зміни, які відбулися стосовно рівня гуманітарних знань студентів в експериментальних групах.

Порівняння результатів зрізів гуманітарних знань студентів контрольних груп, викладання у яких відбувалося без застосування електронного курсу в освітньому середовищі Moodle, суттєвої зміни у позитивній динаміці не виявило. Кількість студентів з високим рівнем гуманітарних знань збільшилась 3 $8 \%$ до 11\%, відсоток студентів з достатнім і низьким рівнями знань зріс з 22 до 25 і з 38 до 42 відповідно, відсоток студентів з низьким рівнем знань зменшився з 32\% до 22\%. Дані, отримані до і після проведення дослідження, представлено у таблиці 1.

Табл. 1. Порівняння рівнів гуманітарних знань студентів контрольних груп перед і після дослідження

\begin{tabular}{|l|c|c|}
\hline $\begin{array}{c}\text { Рівні гуманітарних знань } \\
\text { студентів контрольних груп }\end{array}$ & Перед дослідженням, \% & Після дослідженням, \% \\
\hline Високий & 8 & 11 \\
\hline Достатній & 22 & 25 \\
\hline Низький & 38 & 42 \\
\hline Початковий & 32 & 22 \\
\hline
\end{tabular}

Така відмінність у позитивній динаміці рівнів гуманітарних знань пояснюється, на нашу думку, підвищенням продуктивності й ефективності освітнього процесу; посиленням інтересу до вивчення іноземної мови; оперативністю зворотного зв'язку, завдяки використанню електронного навчального 
курсу Сумського національного аграрного університету з дисципліни «Іноземна мова за професійним спрямуванням».

Отже, аналіз результатів дослідження засвідчив, що використання освітньої платформи Moodle забезпечує ефрективне засвоєння гуманітарних знань завдяки розширенню можливостей доступу студентів аграрних спеціальностей до якісного навчального матеріалу; індивідуалізації освітнього процесу у відповідності до потреб та можливостей студентів, застосуванню сучасних психологопедагогічних та інформаційно-комунікаційних технологій, забезпеченню постійного зворотного зв'язку 3 викладачем та контролю якості засвоєних знань.

\section{IV Обговорення}

Хоча застосування технологій електронного навчання у процесі викладання іноземних мов у Сумському національному аграрному університеті виявилося успішним, все-таки питання $є$ спірним, оскільки Moodle спочатку не створювався як інструмент для вивчення мов [18].

Незважаючи на численні переваги та передові методи навчання, він також зустрічає і негативні реакції студентів та викладачів у всьому світі, які спеціалізуються у галузі вивчення іноземних мов.

Проведені останнім часом дослідження показують, що більшість студентів (95 \%) вважають, що доступність навчальних матеріалів завдяки Moodle $€$ великою перевагою та можливістю отримати додаткові кредити (83 \%). Але, в той же час, викладачі повідомили про негативну реакцію тих студентів, які не прагнуть виконати всі види діяльності, розроблені на платформі Moodle, особливо ті, що потребують академічних навичок аналізу, порівняння та коментування (75\%), а також робити експертну перевірку рівня отриманих знань (понад 60 \%). Було зазначено, що причиною було те, що студенти не мали навичок самостійного навчання та самостійної пошукової діяльності [19]. Але ми приєднуємось до думки, що робота з Moodle дозволяє студентам розвивати самодисципліну та навички самостійно працювати 3 цільовими навчальними матеріалами, що включає визнання необхідності окремого самостійного навчання без допомоги вчителя; розвивати вміння вчитися завдяки інтеграції формального навчання (обов'язкові курси та контент, завантажувані на платформу Moodle) та неформального навчання поза аудиторією та поза контролем викладача. Індивідуальна робота 3 електронним навчальним курсом з іноземної мови стимулює студентів орієнтуватися в загальній освітній проблемі, вибирати основні засоби навчання, наприклад, для підготовки творчих завдань, таких як проекти, блоги, записи, Інтернет квести, тематичні дослідження [14]. Крім того, оволодіння іноземними мовами за допомогою ІКТ як засобами інформації, комунікації та формування знань, передбачає розвиток цифрової компетентності, а також набуття навичок критичного мислення [21].

Загалом, як було встановлено іншим педагогічним експериментом, студенти стверджують, що важче організувати власну навчальну діяльність з вивчення англійської мови на платформі Moodle, ніж відвідувати лекції та брати участь у командній роботі. Більше того, студенти бажали більше особистого контакту, вказуючи на повільну взаємодію зі своїми вчителями під час використання технологій електронного навчання [15]. Сучасні дослідження доводять, що цю проблему можна вирішити за допомогою чатів. Студенти з ентузіазмом сприймають можливості зустрітися он-лайн у чаті; спілкуватися з викладачем та своїми одногрупниками безпосередньо-віртуально, що сприяє позитивній атмосфрері в групі та почуттю спільності. Студенти, які взяли участь в опитуванні, повідомили, що використання IКT відкрило нові канали спілкування та спільної роботи 3 викладачами та одногрупниками, заохочуючи мотивацію студентів та активну участь у навчанні, розвиваючи процеси взаємного оцінювання викладачів та студентів і зворотній зв'язок [17].

Проведені опитування також вказують на те, що в професійно-технічних навчальних закладах ІКТ (зокрема, електронні курси на платформі Moodle) можуть використовуватися для активізації гуманітарних знань та полегшення навчання, заощаджуючи час та сприяючи індивідуалізованому підходу, порівняно з традиційним навчанням [20]. Більше того, і студенти, і викладачі потребують поглибленої підготовки для застосування ІКТ, що включає формування достатнього рівня навичок використання програмного забезпечення, веб-сайтів та інших інструментів, здатних підтримувати реалізацію стратегій та проектів, створення навчальних середовищ, що включають новітні психологопедагогічні досягнення, а також соціально-виховний контекст. Навчання їх також має бути зосереджене на заохоченні позитивних емоцій та мотивації студентів. Ця умова вважається вирішальною для 
питання впровадження ІКТ в навчальний процес для задоволення вимог викладачів та особливостей і потреб студентів [22].

\section{V Висновки}

На основі вивчення наукових джерел, приходимо до висновку, що сьогодні компетентний фахівець аграрного профілю має чітко, послідовно, логічно і адекватно висловлювати власну позицію рідною та іноземною мовами; робити цікаві презентації; брати участь у міжнародних професійних програмах, сприяти впровадженню інноваційних інформаційно-комунікаційних технологій у сільських районах. Отже, підвищення рівня гуманітарних знань фахівців аграрної галузі можна досягнути завдяки навчанню іноземним мовам за професійним спрямуванням засобами інноваційної освіти, зокрема дистанційним електронним курсам на базі платформи Moodle.

Таким чином, проведене дослідження показало ефективність і доцільність застосування електронного навчального курсу з дисципліни «Іноземна мова за професійним спрямуванням», створеного на базі освітньої платформи Moodle для активізації:

а) теоретичного матеріалу, завдяки застосуванню комплексу засобів презентації (звук, графіка, мультиплікація, відео, текст), максимальному використанню аудіоформату, показу явищ у динаміці; комплексності дидактичних матеріалів (залученню до структури словників, редакторів тексту);

б) практичного матеріалу, завдяки наявності належної послідовності вправ, які формують і активізують відповідні гуманітарні знання, навички і вміння; чіткому розмежуванню тренувальних і контролюючих вправ; наявності специфрічних комп'ютерних видів завдань, які складно або неможливо виконати без використання комп'ютера; можливості перегляду, аналізу і виправлення помилок.

\section{Бібліографічні посилання}

1. Білоцерковець М. Дидактичні умови освоєння теоретичних знань в евристичному навчанні при вивченні іноземної мови студентами немовних спеціальностей. Матеріали Міжрегіональної науково-практичній конференції з міжнародною участю «Педагогічне забезпечення творчої самореалізації особистості в інноваційній освіті». Суми, 2013, с. 138.

2. Биков В. Дистанційна освіта: актуальність, особливості і принципи побудови, шляхи розвитку та сфера застосування. Інформаційне забезпечення навчально-виховного процесу: інноваційні засоби і технології. К, 2005, с. 77-92.

3. Губіна О. Інноваційні технології в системі сучасної освіти. Актуальні проблеми наукового й освітнього простору в умовах поглиблення євроінтеграційних процесів, І, 2015, с. 101-103.

4. Драч А. Технологія розроблення програмних продуктів для навчання читання художніх текстів (на прикладі «English for philologists: aspect of reading»). Інформаційні технології і засоби навчання, 2018, Tом 67, №5. URL: https://journal.iitta.gov.ua/index.php/itt/article/view/2136 (дата звернення 19.01.2020).

5. Меморандум международного симпозиума ЮНЕСКО “Фундаментальное (естественнонаучное и гуманитарное) университетское образование”. Высшее образование в России, 1994, № 4.

6. Положення про дистанційне навчання. Наказ Міністерства освіти і науки України від 25. 04 . 2013 № 466 . URL: http://zakon2.rada.gov.ua/laws/show/z07 03 (дата звернення 15.01.2020).

7. Положення про дистанційне навчання у Сумському національному аграрному університеті. URL: http://cdn.sau. sumy.ua/cdn/ regulatory /documents/polozhennja_dn_snau.pdf. (дата звернення 15.01.2020).

8. Поплавська С. Формування готовності студентів медичних коледжів до комунікативної взаємодії у професійній діяльності", дис. канд. пед. наук, Житомир, 2009, с. 128.

9. Сердюков П. Теоретические основы обучения иностранным языкам в языковом вузе с применением информационных технологий, дис. д-ра пед. наук, Киев, 1997, с. 234.

10. Томіліна А. Використання електронної платформи Moodle при контролі й оцінюванні з англійської мови у вищому навчальному закладі. Теорія і практика використання системи управління навчанням Moodle. Київ, КНУБА, 2013, с. 67.

11. Триус Ю. Система електронного навчання BH3 на базі MOODLE. Черкаси, ЧДТУ, 2012, 222 с.

12. Форостюк І. Використання платформи Moodle в процесі викладання іноземних мов у нелінгвістичних вищих навчальних закладах. Науковий вісник Міжнародного гуманітарного університету. Сер.:Філологія, № 31, Т. 3, 2017, с. 191-193.

13. Щепова Д. Місце соціально-гуманітарних дисципін у системі аграрної освіти Науковий вісник мелітопольського державного педагогічного університету. URL: http://ojs.mdpu.org.ua/index.php/nv/article/view/937. 2017, (дата звернення 27.01.2020).

14. Boćković, V., Gajić, T., \& Tomić, I. Moodle in English language teaching. Impact of Internet on Business activities in Serbia and Worldwide: Uticaj Interneta naposlovanje u Srbiji i svetu. 2014. URL: https://SInteZa-2014-480-483. (дата звернення 25.01.2.20). doi: 10.15308/SInteZa-2014-480-483.

15. Gluchmanova, M. Using the Moodle Platform in English Teaching. TEM Journal, 5(4), 2016. P. 492-497. doi: 10.18421/TEM5413. 
16. Husar, J., \& Duplakova, D. Evaluation of Foreign Languages Teaching in LMS: Conditions by Facility and Discrimination index. TEM journal, 5(1), 2016. P. 44-49.

17. Knežević, Ž. Učenje jezika pomoću računara. Mi o jeziku, jezik o nama [Learning languages using computers. We are about language, language about us.]. Zbornik radova sa II konferencije Dručtva za primijenjenu lingvistiku Crne Gore, 2012. P. 217223.

18. Moodle Docs. About Moodle. Philosophy [online]. URL: https://docs.moodle.org/34/en/Philosophy. (дата звернення 25.01.2.20).

19. Rymanova, I., Baryshnikov, N., \& Grishaevac, A. E-course Based on the LMS Moodle for English Language Teaching: Development and Implementation of Results. XV International Conference "Linguistic and Cultural Studies: Traditions and Innovations", LKTI, 2015. P. 9-11.

20. Shamim, M. R. H., \& Raihan, M. A. Effectiveness of using ICTs to promote teaching and learning in technical education: Case of Bangladesh. International Journal of Vocational and Technical Education, 8(2), 2016. P. 12-19.

21. Staker, H., \& Horn, M. Classifying K-12 Blended learning. San Francisco, CA: Innosight Institute, 2012, 325 p. 22. Tomlinson, B., \& Wittaker, C. Blended Learning in English Language Teaching: Course Design and Implementation. London: British Council, 2013, $254 \mathrm{p}$.

\section{References}

1. Bilotserkovets, M. (2013). Didactic conditions for the development of theoretical knowledge in heuristic learning in the study of foreign languages by students of non-native specialties. mat. of Interregional scientific-practical conference with international participation "Pedagogical support of creative self-realization of the person in innovative education". Sumy, P. 138. (in Ukrainian)

2. Bykov, V. (2005). Distant Education: Actuality, Peculiarities and Principles of Construction, Developmental Areas and Scope, Information Support of the Educational Process: Innovative Tools and Technologies, p.77-92. (in Ukrainian)

3. Gubina, O. (2015). Innovative Technologies in the System of Modern Education. Actual problems of scientific and educational space in conditions of deepening of European integration processes, I, c. 101-103. (in Ukrainian)

4. Drach, A. (2018). Technology for the development of software products for teaching reading of artistic texts (for example, "English for philologists: aspect of reading"). Information Technologies and Learning Tools, Vol. 67, No. 5. URL: https://journal.iitta.gov.ua/index.php/itt/article/view/2136 (acceded 19.01.2020). (in Ukrainian)

5. Memorandum of the UNESCO International Symposium "Fundamental (Natural Sciences and Humanities) University Education". (1994). Higher Education in Russia, No. 4. (in Russian)

6. Provision on distance education. Order of the Ministry of Education and Science of Ukraine dated 04/25/2013 No. 466. URL: http: //zakon2.rada.gov.ua/laws/show/z07 03 (acceded 15.01.2020). (in Ukrainian)

7. Regulations on distance learning at Sumy National Agrarian University. URL: http: II cdn.snau. edu.ua/cdn/registration/docs/polozhennja_dn_snau.pdf (acceded 15.01.2020). (in Ukrainian)

8. Poplavskaya, C. (2009). Formation of readiness of students of medical colleges for communicative interaction in professional activity. Diss. Cand. in Ped., Zhytomyr, P. 128. (in Ukrainian)

9. Serdyukov, P. (1997). Theoretical bases of teaching foreign languages in the language university with the use of information technologies. Diss. Dr. in Ped., Kiev, P. 234. (in Russian)

10. Tomilina, A. (2013). Using the Moodle Electronic Platform for Control and Assessment of English at a Higher Educational Institution. Theory and practice of using Moodle learning management system. (Kyiv, KNUBA), P. 67. (in Ukrainian)

11. Trius, Y. (2012). The system of e-learning of higher education institutions based on MOODLE. Cherkasy: ChTTU, 222 p. (in Ukrainian)

12. Forostyuk, I. (2017). Using the Moodle Platform in the Teaching of Foreign Languages in Non-linguistic Higher Educational Institutions. Scientific Bulletin of the International Humanitarian University. Ser.: Philology, No. 31, Vol. 3, p.191-193. (in Ukrainian)

13. Shchepova, D. (2017). The Place of Social and Humanitarian Disciplines in the System of Agrarian Education. Scientific Herald of Melitopol State Pedagogical University. URL: http://ojs.mdpu.org.ua/index.php/nv/article/view/937 (acceded 27.01.2020). (in Ukrainian)

14. Boćković, V., Gajić, T., \& Tomić, I. (2014). Moodle in English language teaching. Impact of Internet on Business activities in Serbia and Worldwide: Uticaj Interneta naposlovanje u Srbiji i svetu. URL: https://SInteZa-2014-480-483. doi: 10.15308/SInteZa-2014-480-483 (acceded 25.01.2020).

15. Gluchmanova, M. (2016). Using the Moodle Platform in English Teaching. TEM Journal, 5(4), 492-497. doi: 10.18421/TEM5413.

16. Husar, J., \& Duplakova, D. (2016). Evaluation of Foreign Languages Teaching in LMS: Conditions by Facility and Discrimination index. TEM journal, 5(1), 44-49.

17. Knežević, Ž. (2012). Učenje jezika pomoću računara. Mi o jeziku, jezik o nama [Learning languages using computers. We are about language, language about us.]. Zbornik radova sa II konferencije Dručtva za primijenjenu lingvistiku Crne Gore, 217223.

18. Moodle Docs. About Moodle Philosophy [online]. URL: https://docs.moodle.org/34/en/Philosophy (acceded 27.01.2020).

19. Rymanova, I., Baryshnikov, N., \& Grishaevac, A. (2015). E-course Based on the LMS Moodle for English Language Teaching: Development and Implementation of Results. XV International Conference "Linguistic and Cultural Studies: Traditions and Innovations", LKTI, 9-11. 
20. Shamim, M. R. H., \& Raihan, M. A. (2016). Effectiveness of using ICTs to promote teaching and learning in technical education: Case of Bangladesh. International Journal of Vocational and Technical Education, 8(2), 12-19.

21. Staker, H., \& Horn, M. (2012). Classifying K-12 Blended learning. San Francisco, CA: Innosight Institute, 325 p. [22] Tomlinson, B., \& Wittaker, C. (2013). Blended Learning in English Language Teaching: Course Design and Implementation. London: British Council, 254p.

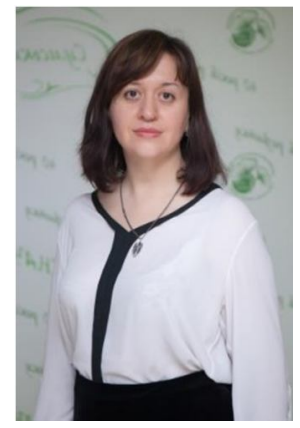

Білоцерковець Марина Анатоліївна,

кандидат педагогічних наук, доцент, старший викладач кафедри іноземних мов,

Сумський національний аграрний університет,

40000, в. Г. Кондратьєва 160, Суми, Украина.

Тел. (0542)222448. mbelotserkovets@yahoo.com.

\section{Bilotserkovets Marina Anatoliivna,}

Candidate in Pedagogy, Associate Professor, Senior Lecturer of Foreign Languages Department,

Sumy National Agrarian University,

40000, G. Kondratiyev street, 160, Sumy, Ukraine.

Tel. (0542)222448. mbelotserkovets@yahoo.com:

ORCID: 0000-0003-4692-3444

Researcher ID: W-6414-2019

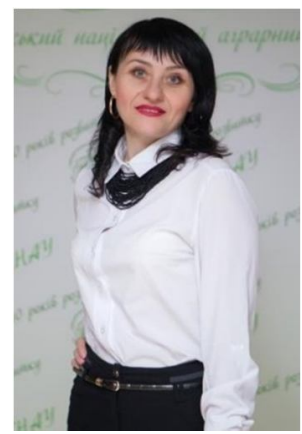

\section{Губіна Оксана Юріївна,}

кандидат педагогічних наук, старший викладач кафедри іноземних мов,

Сумський національний аграрний університет,

40000, в. Г. Кондратьєва 160, Суми, Украина.

Тел. (0542)222448.gubinaoxana_@ukr.net.

\section{Gubina Oksana Yuriivna,}

Candidate in Pedagogy, Associate Professor, Senior Lecturer of Foreign Languages Department,

Sumy National Agrarian University,

40000, G. Kondratiyev street, 160, Sumy, Ukraine.

Tel. (0542)222448. gubinaoxana_@ukr.net.

ORCID: 0000-0002-3575-5898

Researcher ID: V-9569-2018

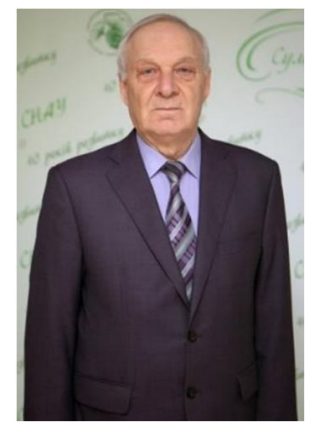

\section{Кобжев Олександр Миколайович,}

кандидат філологічних наук, доцент, доцент кафедри іноземних мов,

Сумський національний аграрний університет,

40000, в. Г. Кондратьєва 160, Суми, Украина.

Тел. (0542)222448. sascha003@ukr.net.

\section{Kobzhev Oleksandr Mykolaiovych,}

Candidate in Phylology, Associate Professor, Associate Professor of Foreign Languages Department,

Sumy National Agrarian University,

40000, G. Kondratiyev street, 160, Sumy, Ukraine.

Tel. (0542)222448. sascha003@ukr.net.

ORCID: 0000-0003-4418-6268

Researcher ID: V-7431-2018

\section{Citation (APA):}

Bilotserkovets, M., Gubina, O., Kobzhev, O. (2020). Implementation of E-Learning Innovative Technologies in The Process of Studying Foreign Languages by Students of Agrarian Universities. Engineering and Educational Technologies, 8 (1), 75-84. doi: https://doi.org/10.30929/2307-9770.2020.08.01.06

\section{Цитування (ДСТУ 8302:2015):}

Білоцерковець М. А., Губіна О. Ю., Кобжев О. М. Впровадження інноваційних технологій електронного навчання у процес засвоєння іноземних мов студентами аграрних 3ВО / Інженерні та освітні технології. 2020. Т. 8. № 1. С. 75-84. doi: https://doi.org/10.30929/2307-9770.2020.08.01.06

Oбсяг cmammi: $\quad$ сторінок - 10 ; умовних друк. аркушів - 1,448 . 